\title{
FAKTOR YANG MEMPENGARUHI MASYARAKAT NON MUSLIM MENJADI NASABAH DENGAN REGRESI LINIER BERGANDA DI PT. BANK MUAMALAT INDONESIA CABANG PEMATANGSIANTAR
}

\author{
${ }^{1}$ Muhammad Fauzan \\ Dosen STIKOM Tunas Bangsa Pematangsiantar, Sumatera Utara-Indonesia \\ Jalan Sudirman Blok A No. 1, 2, 3 Pematangsiantar \\ E-mail: mfauzan57@yahoo.com
}

\begin{abstract}
Abstrak
Penelitian ini dilakukan untuk melihat seberapa besar pengaruh promosi, fasilitas pelayanan dan lokasi mempengaruhi masyarakat non muslim menjadi nasabah PT. Bank Muamalat cabang Pematangsiantar. Data penelitian ini menggunakan data primer yang bersumber dari data yang didapat dari sumber pertama maupun kelompok yaitu kuisioner/angket yang diberikan kepada nasabah Bank Muamalat Indonesia non muslim beralamatkan di Komplek Megaland Blok A Jl. Sangnawaluh No. 6-7, Pematangsiantar dengan jumlah responden 88 orang nasabah. Dari hasil pengolahan data yang ada diperoleh hasil output nilai koefisien determinasi $\left(R^{2}\right)$ menunjukkan bahwa nilai $R=0.750$ dan $R \times R=R^{2}$ sebesar 0.563 atau 56,3\%. Artinya bahwa variabel terikat yaitu masyarakat non muslim menjadi nasabah mampu dijelaskan oleh variabel bebas yaitu promosi, fasilitas pelayanan dan lokasi $(56,3 \%)$ dan sisanya $(43,7 \%)$ dijelaskan oleh variabel lainnya diluar variabel yang digunakan. Berdasarkan uji parsial dari ketiga variabel bebas yaitu promosi, fasilitas pelayanan dan lokasi, maka variabel bebas yang paling berpengaruh terhadap variabel terikat dari masyarakat non muslim menjadi nasabah adalah variabel failitas pelayanan dengan memiliki T-Hitung sebesar 4,042 > T-Tabel 1,980, variabel bebas yang kedua yang paling berpengaruh adalah variabel lokasi dengan memiliki T-Hitung sebesar 4,389 > T-Tabel 1,980 sedangkan variabel promosi memiliki pengaruh negatif dengan memiliki T-Hitung sebesar 1,029 < T-Tabel yaitu sebesar 1,980.
\end{abstract}

Kata kunci: Nasabah non muslim; fasilitas pelayanan; faktor promosi; lokasi

\section{Pendahuluan}

Sejak 1970, lembaga keuangan Islam telah berkembang dengan pesat dan menyebar secara luas diseluruh dunia. Di Indonesia, perkembangan lembaga keuangan Islam mulai dirintis sejak tahun 1980-an. Namun upaya yang lebih intensif dilakukan oleh para aktivis muda Islam pada tahun 1990-an. Yang mencapai puncaknya pada musyawarah Nasional IV Majelis Ulama Indonesia di Jakarta pada tanggal 22-25 Agustus 1990 yang menghasilkan amanat bagi pembentukan kelompok kerja tim perbankan MUI. Hasil kerja tim ini adalah pendirian PT. Bank Muamalat Indonesia pada 1 November 1991. Sebagai bank yang mengusung mekanisme perbankan syariah yang pertama di Indonesia. Dalam kurun waktu dua dasawarsa ini ekonomi Islam berkembang dengan pesat, ditandai dengan banyaknya pendirian bank-bank syariah (baik yang menerapkan sistem murni syariah maupun dual window) serta maraknya lembaga keuangan syariah non bank seperti Baitul Mal Wa Tamwil, BPR Syariah, Asuransi Syariah, Pegadaian Syariah, Reksadana Syariah, 
Pasar Modal Syariah serta Lembaga

Zakat, Infak, Sedekah dan Wakaf.

Praktik perbankan syariah di Indonesia secara perlahan menunjukkan perkembangan yang signifikan. Hal ini ditandai dengan adanya Undang-Undang No. 10 Tahun 1998 tentang perbankan dimana mebolehkan bank-bank konvensional untuk membuka Unit Usaha Syariah (UUS) atau cabang syariah yang biasanya disebut dengan dual banking system dan kini UndangUndang No. 21 Tahun 2008 tentang perbankan syariah, dimana perbankan syariah adalah segala sesuatu yang menyangkut tentang bank syariah dan unit usaha syariah, mencakup kelembagaan, kegiatan usaha serta cara dan proses dalam melaksanakan kegiatan usahanya.

Dalam perkembangannya di Indonesia, praktek perbankan syariah bermula tahun 1992 dengan beroperasinya PT. Bank Muamalat Indonesia, Tbk. PT. Bank Muamalat Indonesia, Tbk merupakan bank pertama murni syariah yang lahir sebagai hasil kerja tim perbankan MUI dan para ikatan Cendikiawan Muslim Indonesia (ICMI) tersebut berdiri pada tanggal 1 November 1991 dengan modal disetor Rp.106.126.382.000,00 telah dapat beroperasi pada tanggal 1 Mei 1992. Berbekal dengan sistem bagi hasil dan penghapusan bunga pada operasional bank konvensional pada umumnya yang dinyatakan riba dalam syariat dan ajaran Islam, Bank Muamalat mampu mengatasi badai krisis dua kali dalam sejarah yaitu krisis 1997-1998 serta krisis global pada tahun 2008.

Salah satu cabang PT. Bank Muamalat Indonesia yang terletak di kota Pematangsiantar memiliki nasabah yang beragam, tidak hanya nasabah dari kalangan umat muslim tetapi juga dari kalangan non muslim yang menjadi nasabahnya. Lebih jelas lihat tabel 1 .

Tabel 1, jumlah nasabah non muslim pada PT. Bank Muamalat
Indonesia cabang Pematangsiantar Tahun 2013-2015.

\begin{tabular}{|c|c|c|}
\hline Tahun & $\begin{array}{c}\text { Jumlah } \\
\text { Nasabah } \\
\text { Keseluruhan }\end{array}$ & $\begin{array}{c}\text { Jumlah } \\
\text { Nasabah Non } \\
\text { Muslim } \\
\end{array}$ \\
\hline 2013 & 18391 & 535 \\
\hline 2014 & 21345 & 633 \\
\hline 2015 & 25746 & 800 \\
\hline & tabel 1 & diatas jumlal \\
\hline
\end{tabular}
nasabah non muslim mengalami peningkatan dari 535 ditahun 2013, meningkat menjadi 633 di tahun 2014 dan terus meningkat menjadi 800 di tahun 2015. Dimana dari 800 jumlah nasabah non muslim adalah etnis Cina, Kristen, Hindu dan Budha, dimana citra Islam dalam pandangan mereka terkesan angker, garis yang keras dan menakutkan. Kenyataan ini patut kita hargai karena tidaklah mudah untuk menarik nasabah dari kalangan Cina non muslim atau pun agama lainnya, dimana kita ketahui kalangan Cina adalah orangorang yang berjiwa bisnis dan memiliki akar yang kuat pada sistem kapitalis. Dimana 800 nasabah ini adalah nasabah penabung dan nasabah pembiayaan. Ini merupakan jumlah yang banyak dimana kita ketahui bahwa di daerah ini begitu banyak berdiri bank-bank lainnya yang sudah lama beroperasi dibandingkan bank Muamalat ini.

Faktor yang dapat mempengaruhi pengambilan keputusan dari nasabah untuk menggunakan jasa perbankan syariah, sangat perlu diperhatikan oleh manajemen perbankan syariah demi kelangsungan dan tetap eksistensinya lembaga tersebut. Diminati atau tidaknya suatu lembaga keuangan sangat dipengaruhi oleh faktor-faktor yang sifatnya psikologis yang menyangkut aspek-aspek prilaku, sikap dan selera.

Penelitian ini bertujuan untuk mengetahui faktor-faktor yang mempengaruhi masyarakat non muslim menjadi nasabah di PT. Bank Muamalat Indonesia cabang Pematangsiantar. 


\section{Metode Penelitian}

Penelitian yang digunakan adalah penelitian lapangan yaitu mengumpulkan data yang bersifat kuantitatif. "Data yang bersifat kuantitatif yaitu data yang berbentuk angket dan perhitungan serta dituangkan dalam bentuk tabel". Kemudian data tersebut diolah dengan menggunakan uji statistik. Penelitian ini khusus membahas tentang faktor-faktor yang mempengaruhi masyarakat non muslim menjadi nasabah di PT. Bank Muamalat Indonesia cabang Pematangsiantar.

Penelitian ini dilaksanakan di PT. Bank Muamalat Indonesia cabang Pematangsiantar beralamatkan di Komplek Megaland Blok A Jl. Sangnawaluh No. 6-7, Pematangsiantar.

Populasi dalam penelitian ini adalah semua masyarakat non muslim yang menjadi nasabah di PT. Bank Muamalat Indonesia cabang Pematangsiantar dari tahun 2013 sampai 2015 adalah 800. Ukuran sampel dengan menggunakan rumus Slovin.

$$
\mathrm{N}=\frac{\mathrm{N}}{1+\mathrm{Ne}^{2}}
$$

Dimana: $\mathrm{n}$ : Jumlah sampel.

$\mathrm{N}$ : Jumlah populasi.

e : Taraf kesalahan (10\%).

Sehingga $: \mathrm{n}=\frac{800}{1+800(0,1)^{2}}=\frac{800}{9}=88$

Teknik pengambilan sampel dalam penelitian ini direncanakan menggunakan Teknik Aksidental Sampling, yaitu teknik pengambilan sampel berdasarkan kebetulan, artinya siapa saja nasabah non muslim yang datang maka dia memiliki sangkut paut dengan karakteristik populasi dan sampel diatas 17 tahun.

\section{Definisi Operasional}

Untuk menjelaskan variabelvariabel yang sudah diidentifikasi maka perlu definisi operasional dari masnigmasing variabel sebagai upaya pemahaman dan penelitian. Definisi dari variabel-variabel yang diteliti adalah sebagai berikut: (1) Keputusan nasabah non muslim (Y) merupakan ketertarikan nasabah non muslim Bank Muamalat Indonesia menjadi nasabah. (2) Promosi $\left(\mathrm{X}_{1}\right)$ adalah usaha-usaha yang dilakukan oleh Bank Muamalat Indonesia untuk memperkenalkan produk-produk mereka kepada masyarakat untuk menarik perhatian nasabah non muslim. (3) Fasilitas pelayanan $\left(\mathrm{X}_{2}\right)$ adalah fasilitasfasilitas yang disediakan oleh Bank Muamalat Indonesia untuk menarik minat nasabah non muslim. (4) Lokasi $\left(\mathrm{X}_{3}\right)$ adalah tempat/lokasi dimana Bank Muamalat Indonesia melakukan aktivitasnya, semakin baik lokasinya maka semakin banyak masyarakat non muslim tertarik untuk menjadi nasabahnya.

\section{Jenis Data dan Sumber Data}

Jenis data yang digunakan adalah data primer. Data primer adalah data yang didapat dari sumber pertama maupun kelompok yaitu kuisioner/angket yang diberikan kepada nasabah Bank Muamalat Indonesia non muslim beralamatkan di Komplek Megaland Blok A Jl. Sangnawaluh No. 6-7, Pematangsiantar dengan jumlah responden 88 orang nasabah.

\section{Teknik Pengumpulan Data}

Pengumpulan data dilakukan penulis dengan teknik pengumpulan data primer dan sekunder sebagai berikut: (1) Data primer adalah: a) Kuisioner/angket adalah teknik pengumpulan data dengan menggunakan pertanyaan-pertanyaan tertulis untuk memperoleh informasi dari responden yaitu promosi, fasilitas pelayanan dan lokasi, b) Observasi yaitu dengan melakukan pengamatan langsung ke lapangan dan c) melakukan 
wawancara langsung kepada responden. (2) Data sekunder yaitu data yang diambil dengan mengumpulkan data yang berhubungan dengan penelitian ini dari PT. Bank Muamalat Indonesia cabang Pematangsiantar dan buku-buku literatur.

Data primer yang dikumpulkan dalam penelitian ini diperoleh melalui teknik angket atau kuesioner yang berisikan pernyataan-pernyataan yang diajukan secara tertulis kepada responden untuk mendapatkan jawaban serta informasi yang diperlukan dalam penelitian ini. Selain itu, data primer juga dapat diperoleh melalui teknik wawancara kepada informan penelitian dan observasi.

Pengumpulan data melalui kuesioner menggunakan skala Likert untuk mengukur dengan lima alternatif, yang terdiri dari:

$\begin{array}{ll}\text { Sangat Setuju (SS) } & =5 \\ \text { Setuju (S) } & =4 \\ \text { Ragu-Ragu (RG) } & =3 \\ \text { Tidak Setuju (TS) } & =2 \\ \text { Sangat Tidak Setuju (STS) } & =1\end{array}$

\section{Analisis Data}

Untuk mendapatkan skala pengukuran atau instrumen yang baik, terlebih dahulu memiliki uji validitas dan realibilitas. Uji validitas dan reliabilitas kuesioner dilakukan untuk menguji apakah kuesioner layak digunakan sebagai instrumen penelitian. Valid berarti instrumen tersebut digunakan untuk mengukur apa yang seharusnya diukur dan reliable berarti instrumen yang digunakan beberapa kali untuk mengukur objek yang sama, akan menghasilkan data yang sama.

$$
\begin{aligned}
& \text { Untuk menguji validitas } \\
& \text { instrumen yang digunakan dalam } \\
& \text { penelitian menggunakan nilai practicical } \\
& \text { significance. Nilai validitas }>0,30 \text { adalah } \\
& \text { nilai yang dapat diterima dalam analisis } \\
& \text { faktor. } \\
& \text { Sedangkan reliabilitas, pengujian } \\
& \text { yang sering digunakan adalah alpha }
\end{aligned}
$$

cronbach. Pada teknik ini nilai 0,60 sering digunakan sebagai nilai reliabilitas dalam suatu penelitian. Rumus yang digunakan adalah:

$$
\begin{aligned}
& \mathrm{r}=\left[\frac{\mathrm{k}}{(\mathrm{k}-1)}\right]\left[\begin{array}{l}
1-\sum \sigma^{2} \mathrm{~b} \\
\sigma^{2}{ }_{1}
\end{array}\right] \\
& \mathrm{r} \quad=\text { Reliabilitas konsumen. } \\
& \mathrm{k} \quad=\text { Banyak butir pertanyaan. } \\
& \begin{array}{ll}
\sum \sigma^{2}{ }_{\mathrm{b}} & =\text { Jumlah varians butir. } \\
\sigma^{2}{ }_{1} & =\text { Varians total. }
\end{array}
\end{aligned}
$$

Uji validitas dan reliabilitas kuesioner dalam penelitian ini menggunakan bantuan program SPSS for Windows.

Analisis data menggunakan metode statistik yang dilakukan sebagai berikut:

1. Analisis deskriptif, yaitu salah satu metode analisis dengan cara data yang disusun dan dikelompokkan kemudian disajikan sehingga diperoleh gambaran umum.

2. Uji asumsi klasik, uji asumsi klasik ini dilakukan agar persamaan regresi yang dihasilkan akan valid jika digunakan untuk memprediksi. Beberapa uji tersebut terdiri dari:

a. Uji Normalitas, yaitu pengujian yang digunakan untuk melihat sebuah model regresi, variabel independen, variabel dependen memiliki distribusi normal atau tidak.

b. Uji Heteroskedastisitas merupakan pengujian yang digunakan untuk menguji terjadinya perbedaan variante residual suatu periode pengamatan ke periode pengamatan yang lain atau gambaran hubungan antara nilai yang diprediksi dengan studentized deleted residual nilai tersebut.

c. Uji Multikolinearitas, pengujian yang dipergunakan untuk menguji keterkaitan atau korelasi antara variabel independen dengan variabel dependen dalam model regresi. 


\section{Analisis Korelasi}

Digunakan untuk mengetahui keeratan hubungan antara variabel promosi, fasilitas pelayanan dan lokasi dengan masyarakat non muslim menjadi nasabah di PT. Bank Muamalat Indonesia cabang Pematangsiantar. Semua variabel bebas memiliki pengaruh secara simultan terhadap variabel terikat kemudian variabel satu demi satu akan diuji secara parsial yaitu untuk melihat hubungan variabel bebas dari variabel terikat, dengan variabel lain tetap. Untuk memperoleh hasil yang lebih terarah, maka peneliti menggunakan bantuan program software SPSS.

\section{Analisis Regresi Berganda}

Digunakan untuk mengetahui besarnya hubungan dan pengaruh variabel independen yang jumlahnya lebih dari dua $\left(\mathrm{X}_{1}, \mathrm{X}_{2}, \mathrm{X}_{3}\right)$ terhadap variabel dependen.

Dengan rumus:

$\mathrm{Y}=\mathrm{a}+\mathrm{b}_{1} \mathrm{X}_{1}+\mathrm{b}_{2} \mathrm{X}_{2}+\mathrm{b}_{3} \mathrm{X}_{3}+\mathrm{e}$

Berdasarkan rumus diatas, maka model penelitian ini adalah

$$
M M=a+b_{1} P r+b_{2} F p+b_{3} L+e
$$

Dimana:

$$
\begin{array}{ll}
\mathrm{MM} & =\text { Nasabah Non Muslim } \\
\mathrm{a} & =\text { Konstanta. } \\
\mathrm{b}_{1}, \mathrm{~b}_{2}, \mathrm{~b}_{3} & =\text { Koefisien regresi berganda } \\
\mathrm{Pr} & =\text { Promosi. } \\
\mathrm{Fp} & =\text { Fasilitas Pelayanan. } \\
\mathrm{Lk} & =\text { Lokasi. } \\
\mathrm{e} & =\text { Standar error. }
\end{array}
$$

Dalam analisis regresi ada tiga jenis ketepatan yang diuji, yaitu:

a. Koefisien Determinan $\left(\mathrm{R}^{2}\right)$

Koefisien determinan $\left(\mathrm{R}^{2}\right)$ pada intinya mengukur seberapa kemampuan model dalam menerangkan variabel terikat atau seberapa besar kontribusi variabel bebas $\left(\mathrm{X}_{1}, \mathrm{X}_{2}\right.$ dan $\left.\mathrm{X}_{3}\right)$ yaitu berupa variabel promosi, fasiltas pelayanan dan lokasi terhadap masyarakat non muslim menjadi nasabah yaitu variabel terikat $(\mathrm{Y})$.

Jika $\mathrm{R}^{2}$ semakin besar maka dapat dikatakan bahwa pengaruh variabel bebas $\left(\mathrm{X}_{1}, \mathrm{X}_{2}\right.$ dan $\left.\mathrm{X}_{3}\right)$ adalah besar terhadap variabel terikat $(\mathrm{Y})$. Hal ini berarti model yang digunakan semakin kuat untuk menerangkan pengaruh variabel bebas yang diteliti terhadap variabel terikat. Sebaliknya, jika $\mathrm{R}^{2}$ semakin mengecil (mendekati nol) maka dapat dikatakan bahwa pengaruh variabel bebas $\left(\mathrm{X}_{1}, \mathrm{X}_{2}\right.$ dan $\mathrm{X}_{3}$ ) terhadap variabel terikat $(\mathrm{Y})$ semakin kecil. Hal ini berarti model yang digunakan tidak kuat untuk menerangkan pengaruh variabel bebas yang diterliti terhadap variabel terikat (Y).

b. Uji Signifikan Individual (Uji-T)

Uji-T menunjukkan seberapa besar pengaruh variabel bebas secara individual terhadap variabel terikat. Hipotesis yang akan diuji adalah sebagai berikut:

$\mathrm{H}_{0}: \mathrm{b}_{1}=0$, artinya secara parsial tidak terdapat pengaruh positif dan signifikan dari variabel bebas $\left(\mathrm{X}_{1}, \mathrm{X}_{2}\right.$ dan $X_{3}$ ) yaitu berupa varibel peromosi, fasilitas pelayanan dan lokasi terhadap minat menabung nasabah non muslim yaitu variabel terikat $(\mathrm{Y})$.

$\mathrm{H}_{0}: \mathrm{b}_{1} \neq 0$, artinya secara parsial terdapat pengaruh yang positif dan signifikan dari variabel bebas $\left(\mathrm{X}_{1}, \mathrm{X}_{2}\right.$ dan $\left.X_{3}\right)$ yaitu berupa variabel promosi, fasilitas pelayanan dan lokasi terhadap minat menabung nasabah non muslim yaitu variabel terikat (Y).

Kriteria pengambilan keputusan untuk hipotesis diatas adalah:

$\mathrm{H}_{0}$ diterima jika $\mathrm{t}_{\text {hitung }}<\mathrm{t}_{\text {tabel }}$ pada $\alpha=$ $5 \%$.

$\mathrm{H}_{\mathrm{a}}$ diterima jika $\mathrm{t}_{\text {hitung }}>\mathrm{t}_{\text {tabel }}$ pada $\alpha=$ $5 \%$. 
c. Uji Signifikansi Simultan (Uji-F)

Uji-F pada dasarnya

menunjukkan apakah semua variabel bebas yang dimasukkan dalam model mempunyai hubungan secara bersamasama terhadap variabel terikat. Hipotesis yang akan diuji adalah:

$\mathrm{H}_{0}: \mathrm{r}_{1}=\mathrm{r}_{2}=\mathrm{r}_{3}=0$, artinya secara bersama-sama tidak terdapat hubungan yang positif dan siginifikan dari variabel bebas $\left(\mathrm{X}_{1}, \mathrm{X}_{2}\right.$ dan $\left.\mathrm{X}_{3}\right)$ yaitu berupa variabel promosi, fasilitas pelayanan dan lokasi terhadap minat menabung nasabah non muslim yaitu variabel terikat (Y).

$\mathrm{H}_{\mathrm{a}}: \mathrm{r}_{1}=\mathrm{r}_{2}=\mathrm{r}_{3} \neq 0$, artinya secara bersama-sama terdapat hubungan yang posistif dan signifikan dari variabel bebas $\left(\mathrm{X}_{1}, \mathrm{X}_{2}\right.$ dan $\left.\mathrm{X}_{3}\right)$ yaitu berupa variabel promosi, fasilitas pelayanan dan lokasi terhadap minat menabung nasabah non muslim yaitu variabel terikat (Y).

Kriteria pengambilan keputusan:

$\mathrm{H}_{0}$ diterima jika $\mathrm{t}_{\text {hitung }}<\mathrm{F}_{\text {tabel }}$ pada $\alpha=$ $5 \%$.

$\mathrm{H}_{\mathrm{a}}$ diterima jika $\mathrm{t}_{\text {hitung }}>\mathrm{F}_{\text {tabel }}$ pada $\alpha=$ $5 \%$.

\section{Hasil dan Pembahasan}

Sejarah pendirian Bank Muamalat berawal dari lokakarya Bunga Bank dan Perbankan yang diselenggarakan Majelis Ulama Indonesia pada tanggal 18-20 Agustus 1990 di Cisarua, Bogor. Ide ini berlanjut dalam Musyawarah Nasional IV Majelis Ulama Indonesia di Hotel Sahid Jaya, Jakarta, pada tanggal 22-25 Agustus 1990 yang diteruskan dengan pembentukan kelompok kerja untuk mendirikan bank murni syariah pertama di Indonesia.

Realisasinya dilakukan pada tanggal 1 November 1991 yang ditandai dengan penandatangan akte pendirian PT Bank Muamalat Indonesia di Hotel Sahid Jaya berdasarkan Akte Notaris Nomor 1 tanggal 1 November 1991 yang dibuat oleh notaris Yudo Paripurno, SH dengan Izin Menteri Kehakiman Nomor C2.2413.T.01.01 tanggal 21 Maret
1992/Berita Negara Republik Indonesia tanggal 28 April 1992 Nomor 34.

Pada saat penandatanganan akte pendirian ini diperoleh komitmen dari berbagai pihak untuk membeli saham sebanyak Rp. 84 miliar. Kemudian dalam acara silaturahmi pendirian di Istana Bogor diperoleh tambahan dana dari masyarakat Jawa Barat senilai Rp. 106 miliar sebagai wujud dukungan mereka.

Dengan modal awal tersebut dan berdasarkan Surat Keputusan Menteri Keuangan RI Nomor 1223/MK.013/1991 tanggal 5 November 1991 serta izin usaha yang berupa Keputusan Menteri Keuangan Republik Indonesia Nomor 430/KMK.013/1992 tanggal 24 April 1992. Bank Muamalat Indonesia mulai beroperasi pada tanggal 1 Mei 1992 bertepatan 27 Syawal 1412 H. Pada tanggal 27 Oktober 1994, Bank Muamalat Indonesia mendapat kepercayaan dari Bank Indonesia sebagai Bank Devisa.

\section{Produk-Produk Bank Muamalat Indonesia}

Dalam menjalankan kegiatan usahanya sehari-hari PT. Bank Muamalat Indonesia cabang Pematangsiantar dapat dibagi dalam beberapa jenis kegiatan yang meliputi:

a.Produk Penghimpunan Dana (Funding)

Produk-produk pengimpunan

dana (funding) yang terdapat di PT.

Bank Muamalat Indonesia cabang Pematangsiantar, yaitu Tabungan Muamalat Prima, Tabungan Muamalat Rencana, Tabungan Muamalat Umroh, Tabungan Haji Arafah, Tabungan Haji Arafah Dollar, Tabungan Muamalat Dollar, Tabungan Muamalat Sahabat, Tabunganku, Giro Muamalat Ultima, Giro Muamalat Attijary, Deposito Mudharabah, Deposito Fulinves, Pensiun terproteksi Muamalat dan Pensiun Untuk Kompensasi Pesangon. 


\section{b. Produk Penyaluran Dana (Lending)}

Produk-produk penyaluran dana (lending) yang terdapat di PT. Bank Muamalat Indonesia cabang Pematangsiantar, yaitu Murabahah (Jual Beli), Jual Beli Salam, Jual Beli Istishna', Mudharabah (Bagi Hasil), Musyarakah (Kongsi), Ijarah (Sewa Menyewa) dan Ijarah Muntahiya Bittamlik.

\section{c. Produk Jasa}

Produk-produk jasa yang terdapat di PT. Bank Muamalat Indonesia cabang Pematangsiantar, yaitu Wakalah (Perwakilan), Kafalah (Penjaminan), Hawalah (Pengalihan Hutang), Rahn (Gadai), Qardh (Pinjaman Kebajikan), Sharf (Valuta Asing) dan layanan e-Muamalat yang terdiri dari Salam Muamalat, Internet Banking Muamalat, Mobile Banking Muamalat, Virtual Account Muamalat, Cash Management System Muamalat dan Gerai Muamalat (PPOB).

\section{Deskripsi Variabel Penelitian}

Variabel penelitian ini merupakan instrumen pemilihan nasabah non muslim Bank Muamalat Indonesia yang diteliti melalui promosi, fasiltas pelayanan dan lokasi. Data-data dari variabel ini diungkap menggunakan kuesioner sebanyak 20 pertanyaan dan 88 responden. Gambaran dari masingmasing variabel nasabah tersebut dapat dilakukan dengan analisis deskriptif presentase. Berikut ini diasjikan hasil analisis deskriptif persentase tiap variabel.

\section{Deskriptif Variabel Promosi $\left(X_{1}\right)$}

Butir pertanyaan 1 mengenai banyaknya media yang digunakan untuk melakukan promosi memudahkan saudara untuk memahami Bank Muamalat mayoritas memberikan jawaban sangat setuju sebanyak 60 responden $(68,1 \%)$. Butir pertanyaan 2 mengenai anda mengetahui produkproduk Bank Muamalat dari sosialisasi yang dilakukan Bank Muamalat, mayoritas memberikan jawaban setuju sebanyak 60 responden $(68,1 \%)$. Butir pertanyaan 3 mengenai Bank Muamalat ditujukan untuk semua lapisan masyarakat, mayoritas memberikan jawaban setuju 46 responden (52,3\%). Butir pertanyaan 4 mengenai pemberian insentif agar membeli produk Bank Muamalat telah membuat nasabah tertarik, mayoritas memberikan jawaban 63 responden $(71,6 \%)$. Butir pertanyaan 5 mengenai Bank Muamalat sering memberikan hadiah kepada nasabahnya yang loyal, mayoritas memberikan jawaban setuju 63 responden $(71,6 \%)$.

\section{Deskriptif Variabel Fasilitas Pelayanan $\left(X_{2}\right)$}

Butir pertanyaan 1 Bank Muamalat memiliki peralatan teknologi yang mutakhir, mayoritas memberikan jawaban sangat setuju sebanyak 55 responden $(62,5 \%)$. Butir pertanyaan 2 sikap ramah yang diberikan karyawan sudah baik, mayoritas memberikan jawaban setuju 65 responden $(73,9 \%)$. Butir pertanyaan 3 mengenai karyawan Bank Muamalat memiliki kemampuan yang baik dalam menyampaikan informasi, mayoritas memberikan jawaban setuju 59 responden (67\%). Butir pertanyaan 4 mengenai pelayanan Bank Muamalat selalu tanggap dan cepat, mayoritas memberikan jawaban setuju 54 responden $(61,3 \%)$. Butir pertanyaan 5 mengenai karyawan Bank Muamalat bertanggung jawab kepada nasabahnya dari awal hingga selesai, mayoritas memberikan jawaban setuju 59 responden $(67 \%)$.

\section{Deskriptif Variabel Lokasi $\left(X_{3}\right)$}

Butir pertanyaan 1 lokasi Bank Muamalat strategis karena berada di pusat pemerintahan, mayoritas memberikan jawaban sangat setuju sebanyak 67 responden $(76,1 \%)$. Butir 
pertanyaan 2 Bank Muamalat terletak dekat kantor lain, mayoritas memberikan jawaban sangat setuju 52 responden (59\%). Butir pertanyaan 3 mengenai Bank Muamalat dekat dengan pusat perbelanjaan, mayoritas memberikan jawaban sangat setuju 52 responden (59\%). Butir pertanyaan 4 kondisi gedung aman, mayoritas memberikan jawaban sangat setuju 40 responden $(45,4 \%)$. Butir pertanyaan 5 lokasi yang mudah dijangkau oleh kendaraan umum, mayoritas meberikan jawaban setuju 49 responden $(55,7 \%)$.

Deskriptif Variabel Masyarakat Non Muslim Menjadi Nasabah (Y)

Butir pertanyaan 1 menjadi nasabah di Bank Muamalat Indonesia aman, mayoritas memberikan jawaban sangat setuju sebanyak 61 responden $(69,3 \%)$. Butir pertanyaan 2 Bank Muamalat Indonesia sudah terkenal dan terpercaya, mayoritas memberikan jawaban setuju 63 responden $(71,5 \%)$. Butir pertanyaan 3 pimpinan Bank Muamalat Indonesia terdiri dari orangorang yang terkenal dan terpercaya, mayoritas memberikan jawaban setuju 54 responden $(61,4 \%)$. Butir pertanyaan 4 dengan mempertimbangkan variabel promosi, fasiltas pelayanan dan lokasi saudara berkeinginan untuk menjadi nasabah di Bank Muamalat Indonesia, mayoritas memberikan jawaban setuju 57 responden $(64,8 \%)$. Butir pertanyaan 5 saudara akan menyarankan kepada orang lain untuk menjadi nasabah di Bank Muamalat Indonesia, mayoritas memberikan jawaban setuju 56 responden $(63,6 \%)$.

\section{Uji Validitas}

\section{a. Variabel Promosi}

Dengan mengikuti persyaratan bahwa sebuah pernyataan dinyatakan valid maka nilai alpha tiap butir pertanyaan diatas harus lebih besar dari 0,211 , berdasarkan pengolahan data yang ada maka hasil analisis outputnya adalah:
Butir 1, dengan nilai $r_{\text {hitung }}>r_{\text {tabel }}$ yaitu $0,410>0,211$ sehingga dinyatakan valid.

Butir 2, dengan nilai $r_{\text {hitung }}>r_{\text {tabel }}$ yaitu $0,352>0,211$ sehingga dinyatakan valid.

Butir 3, dengan nilai $r_{\text {hitung }}>r_{\text {tabel }}$ yaitu 0,268>0,211 sehingga dinyatakan valid.

Butir 4, dengan nilai $r_{\text {hitung }}>r_{\text {tabel }}$ yaitu $0,428>0,211$ sehingga dinyatakan valid.

Butir 5, dengan nilai $r_{\text {hitung }}>r_{\text {tabel }}$ yaitu $0,391>0,211$ sehingga dinyatakan valid.

Dengan demikian dapat diambil kesimpulan bahwa didalam pernyataan promosi semua butir pernyataan dinyatakan valid.

\section{b. Variabel Fasilitas Pelayanan}

Dengan mengikuti persyaratan bahwa sebuah pernyataan dinyatakan valid maka nilai alpha tiap butir pertanyaan diatas harus lebih besar dari 0,211 , berdasarkan pengolahan data yang ada maka hasil analisis outputnya adalah: Butir 1, dengan nilai $r_{\text {hitung }}>r_{\text {tabel }}$ yaitu $0,491>0,211$ sehingga dinyatakan valid.

Butir 2, dengan nilai $r_{\text {hitung }}>r_{\text {tabel }}$ yaitu $0,515>0,211$ sehingga dinyatakan valid.

Butir 3, dengan nilai $r_{\text {hitung }}>r_{\text {tabel }}$ yaitu $0,623>0,211$ sehingga dinyatakan valid.

Butir 4, dengan nilai $r_{\text {hitung }}>r_{\text {tabel }}$ yaitu $0,501>0,211$ sehingga dinyatakan valid.

Butir 5, dengan nilai $r_{\text {hitung }}>r_{\text {tabel }}$ yaitu $0,541>0,211$ sehingga dinyatakan valid.

Dengan demikian dapat diambil kesimpulan bahwa didalam pernyataan fasilitas pelayanan semua butir pernyataan dinyatakan valid.

\section{c. Variabel Lokasi}

Dengan mengikuti persyaratan bahwa sebuah pernyataan dinyatakan valid maka nilai alpha tiap butir pertanyaan diatas harus lebih besar dari 0,211 , berdasarkan pengolahan data yang ada maka hasil analisis outputnya adalah: Butir 1, dengan nilai $r_{\text {hitung }}>r_{\text {tabel }}$ yaitu 0,678>0,211 sehingga dinyatakan valid.

Butir 2, dengan nilai $r_{\text {hitung }}>r_{\text {tabel }}$ yaitu $0,622>0,211$ sehingga dinyatakan valid. 
Butir 3, dengan nilai $r_{\text {hitung }}>r_{\text {tabel }}$ yaitu $0,573>0,211$ sehingga dinyatakan valid.

Butir 4 , dengan nilai $r_{\text {hitung }}>r_{\text {tabel }}$ yaitu $0,655>0,211$ sehingga dinyatakan valid.

Butir 5, dengan nilai $r_{\text {hitung }}>r_{\text {tabel }}$ yaitu 0,447>0,211 sehingga dinyatakan valid.

Dengan demikian dapat diambil kesimpulan bahwa didalam pernyataan lokasi semua butir pernyataan dinyatakan valid.

\section{d. Variabel Masyarakat Non Muslim Menjadi Nasabah}

Dengan mengikuti persyaratan bahwa sebuah pernyataan dinyatakan valid maka nilai alpha tiap butir pertanyaan diatas harus lebih besar dari 0,211 , berdasarkan pengolahan data yang ada maka hasil analisis outputnya adalah: Butir 1, dengan nilai $r_{\text {hitung }}>r_{\text {tabel }}$ yaitu 0,384>0,211 sehingga dinyatakan valid.

Butir 2, dengan nilai $r_{\text {hitung }}>r_{\text {tabel }}$ yaitu 0,389>0,211 sehingga dinyatakan valid.

Butir 3, dengan nilai $r_{\text {hitung }}>r_{\text {tabel }}$ yaitu $0,444>0,211$ sehingga dinyatakan valid.

Butir 4, dengan nilai $r_{\text {hitung }}>r_{\text {tabel }}$ yaitu 0,542>0,211 sehingga dinyatakan valid.

Butir 5, dengan nilai $r_{\text {hitung }}>r_{\text {tabel }}$ yaitu $0,577>0,211$ sehingga dinyatakan valid.

Dengan demikian dapat diambil kesimpulan bahwa didalam pernyataan masyarakat non muslim menjadi nasabah semua butir pernyataan dinyatakan valid.

\section{Uji Reliabilitas}

Salah satu metode pengujian reliabilitas adalah dengan menggunakan metode Alpha Cronbachs. Standar yang digunakan untuk menentukan reliabel tidaknya suatu instrumen penelitian umumnya adalah perbandingan antara nilai $r_{\text {hitung }}$ dengan $r_{\text {tabel }}$ pada taraf kepercayaan $95 \%$ atau tingkat signifikan 5\%. Tingkat reliabilitas dengan metode Alpha Cronbachs diukur pada skala 0 sampai dengan 1. Dan skala tersebut dikelompokkan menjadi 5 kelas range yang sama, maka ukuran ketetapan alpha dapat diinterprestasikan sebagai berikut:

\begin{tabular}{cll}
\hline No & \multicolumn{1}{c}{ Alpha } & Tingkat Reliabilitas \\
\hline 1 & $0,00 \mathrm{~s} / \mathrm{d} 0,20$ & Kurang Reliabel \\
2 & $>0,20 \mathrm{~s} / \mathrm{d}$ & Agak Reliabel \\
3 & 0,40 & Cukup Reliabel \\
4 & $>0,40 \mathrm{~s} / \mathrm{d}$ & Reliabel \\
5 & 0,60 & Sangat Reliabel \\
& $>0,60 \mathrm{~s} / \mathrm{d}$ & \\
& 0,80 & \\
& $>080 \mathrm{~s} / \mathrm{d}$ & \\
& 1,00 & \\
\hline
\end{tabular}

a. Variabel Promosi

Untuk variabel promosi dari outputnya nilai Alpha Cronbachs = 0,606 ternyata lebih besar dari $r_{\text {tabel }}$ 0,211 maka kuesioner yang diuji terbukti reliabel. Karena nilai Alpha Cronbachs 0,606 terletak diantara 0,606 sampai dengan 0,80 sehingga tingkat reliabilitasnya reliabel.

b. Variabel Fasilitas Pelayanan

Untuk variabel fasilitas pelayanan dari outputnya nilai Alpha Cronbachs $=0,762$ ternyata lebih besar dari $r_{\text {tabel }}$ 0,211 maka kuesioner yang diuji terbukti reliabel. Karena nilai Alpha Cronbachs 0,762 terletak diantara 0,606 sampai dengan 0,80 sehingga tingkat reliabilitasnya reliabel.

\section{c. Variabel Lokasi}

Untuk variabel lokasi dari outputnya nilai Alpha Cronbachs = 0,795 ternyata lebih besar dari $r_{\text {tabel }}$ 0,211 maka kuesioner yang diuji terbukti reliabel. Karena nilai Alpha Cronbachs 0,795 terletak diantara 0,606 sampai dengan 0,80 sehingga tingkat reliabilitasnya reliabel.

d.Variabel Masyarakat Non Muslim Menjadi Nasabah

Untuk variabel masyarakat non muslim menjadi nasabah dari outputnya nilai Alpha Cronbachs = 0,707 ternyata lebih besar dari $r_{\text {tabel }}$ 0,211 maka kuesioner yang diuji terbukti reliabel. Karena nilai Alpha Cronbachs 0,707 terletak diantara 
0,606 sampai dengan 0,80 sehingga tingkat reliabilitasnya reliabel.

\section{Uji Normalitas}

Uji normalitas merupakan suatu jenis uji statistik untuk menentukan apakah suatu populasi berdistribusi normal atau tidak. Uji ini penting dilakukan karena sering kali sebelum melakukan pengolahan data pada suatu pengamatan populasi, banyak peneliti mengasumsikan bahwa populasi yang diamati tersebut terdistribusi normal.

Pada normalisasi data dengan normal P-Plot, data pada variabel yang digunakan akan dinyatakan terdistribusi normal. Hal tersebut terjadi karena titiktitik residual tersebut berasal dari data dengan distribusi normal dan mengikuti garis diagonal atau garis linier. Dengan demikian dapat disimpulkan bahwa regresi telah memenuhi normalitas.

\section{Uji Multikolinearitas}

Multikolineritas dapat dideteksi pada model regresi apabila pada variabel terdapat pasangan variabel bebas yang saling berkolerasi kuat satu sama lain. Disamping itu, mulikolinearitas dapat menyebabkan fluktuasi yang besar pada prediksi koefisien regresi, dan juga dapat menyebabkan penambahan variabel independen yang tidak berpengaruh sama sekali.

Bahwa dari hasil pengolahan data yang ada bahwa hasil besaran korelasi antar variabel bebas tampak bahwa hanya variabel lokasi yang mempunyai korelasi yang cukup tinggi dengan variabel promosi dan variabel fasilitas pelayanan dengan tingkt korelasi sebesar -0.479 atau sekitar $47.9 \%$. Oleh karena itu korelasi ini masih dibawah $90 \%$ maka dapat disimpulkan bahwa tidak ada multikolinearitas antar variabel bebas dalam model regresi.

\section{Uji Regresi Berganda}

Regresi berganda adalah analisis regresi dengan menggunakan dua atau lebih variabel bebas. Data untuk penelitian ini diolah dengan menggunakan software SPSS dengan melihat dan mngestimasi parameter variabel yang diamati dari model yang telah ditetapkan. Setelah mendapatkan estimasi model tersebut, maka akan dilakukan dengan uji statistik yaitu uji statistik regresi pada kenormalan.

Berikut ini hasil model regresi yang terbentuk yaitu:

$\mathrm{MM}=2,616+0,109 \mathrm{Pr}+0,358 \mathrm{Fp}+$ 0,398L

Arti dari persamaan regresi berganda yang diperoleh dari nilai konstanta 2,616 jika terjadi 1 kuesioner terhdap promosi maka masyarakat non muslim menjadi nasabah yang dihasilkan sebesar 0,109. Jika fasilitas pelayanan diabaikan, maka akan berpengaruh positif terhadap masyarakat non muslim menjadi nasabah sebesar 2,616. Jika terjadi peningkatan 1 kuesioner terhadap pelayanan maka akan berpengaruh positif terhadap masayarakat non muslim menjadi nasabah yang dihasilkan sebesar 0,358 dan jika lokasi diabaikan maka akan berpengaruh positif terhadap masyarakat non muslim menjadi nasabah sebesar 2,616. Jika terjadi peningkatan 1 kuesioner terhadap lokasi maka akan berpengaruh positif terhadap masyarakat non muslim menjadi nasabah yang dihasilkan sebesar 0,398.

\section{Uji Hipotesis}

a. Pengujian Ketetapan Perkiraan Uji $\mathrm{R}^{2}$

Dari hasil pengolahan data yang ada diperoleh hasil output nilai koefisien determinasi $\left(\mathrm{R}^{2}\right)$ menunjukkan bahwa nilai $\mathrm{R}=0.750$ dan $\mathrm{R} \times \mathrm{R}=\mathrm{R}^{2}$ sebesar 0.563 atau $56,3 \%$. Artinya bahwa variabel terikat yaitu masyarakat non muslim menjadi nasabah mampu dijelaskan oleh variabel bebas yaitu promosi, fasilitas pelayanan dan lokasi $(56,3 \%)$ dan sisanya $(43,7 \%)$ dijelaskan oleh variabel lainnya diluar variabel yang digunakan. 
b. Pengujian Parsial (Uji T-Test Statistik)

Uji T-Test bertujuan untuk mengetahui besarnya pengaruh masing-masing variabel bebas secar individual terhadap variabel terikat. Uji T-Test tersebut dibutuhkan untuk menguji seberapa besar variabel bebas yakni promosi, fasilitas pelayanan dan lokasi mempengaruhi terhadap variabel masyarakat non muslim menjadi nasabah.

Berdasarkan uji parsial dari ketiga variabel bebas yaitu promosi, fasilitas pelayanan dan lokasi, maka variabel bebas yang paling berpengaruh terhadap variabel terikat dari masyarakat non muslim menjadi nasabah adalah variabel failitas pelayanan dengan memiliki $\mathrm{T}$ Hitung sebesar 4,042 > T-Tabel 1,980, variabel bebas yang kedua yang paling berpengaruh adalah variabel lokasi dengan memiliki T-Hitung sebesar 4,389 > T-Tabel 1,980 sedangkan variabel promosi memiliki pengaruh negatif dengan memiliki T-Hitung sebesar 1,029 < T-Tabel yaitu sebesar 1,980 .

c. Pengujian Secara Serempak (Uji FTest Statistik)

Berdasarkan uji ANOVA atau FTest statistik menunjukkan p-value $0.000<0.005$, artinya siginifikan, sedangkan F-hitung 36,057 > 2,68, artinya signifikan. Signifikan disini berarti $\mathrm{H}_{\mathrm{a}} 1$ diterima dan $\mathrm{H}_{0}$ ditolak. Artinya model regresi dapat dipakai untuk memprediksi kinerja minat nasabah non muslim menjadi nasabah di Bank Muamalat Indonesia atau dapat dikatakan promosi, fasilitas pelayanan dan lokasi secara bersamasama berpengaruh terhadap masyarakat non muslim menjadi nasabah.

\section{Kesimpulan}

Berdasarkan hasil pembahasan diatas, penelitian ini dapat disimpulkan bahwa dalam analisis $R$-Square $\left(\mathrm{R}^{2}\right)$ diperoleh angka 0,563 artinya 56,3\% variabel dependen msyarakat non muslim menjadi nasabah dapat dijelaskan oleh variabel bebas yaitu promosi, fasilitas pelayanan dan lokasi $(56,3 \%)$ dan sisanya $(43,7 \%)$ dijelaskan oleh variabel lainnya diluar variabel yang digunakan. Berdasarkan uji parsial dari ketiga variabel bebas yaitu promosi, fasilitas pelayanan dan lokasi, maka variabel bebas yang paling berpengaruh terhadap variabel terikat dari masyarakat non muslim menjadi nasabah adalah variabel failitas pelayanan dengan memiliki T-Hitung sebesar 4,042 > T-Tabel 1,980 , variabel bebas yang kedua yang paling berpengaruh adalah variabel lokasi dengan memiliki $\mathrm{T}$ Hitung sebesar 4,389 > T-Tabel 1,980 sedangkan variabel promosi memiliki pengaruh negatif dengan memiliki $\mathrm{T}$ Hitung sebesar $1,029<\mathrm{T}$-Tabel yaitu sebesar 1,980.

3. Berdasarkan uji ANOVA atau F-Test statistik menunjukkan $p$-value $0.000<$ 0.005 , artinya siginifikan, sedangkan Fhitung $36,057>2,68$, artinya signifikan. Signifikan disini berarti $\mathrm{H}_{\mathrm{a}} 1$ diterima dan $\mathrm{H}_{0}$ ditolak. Artinya model regresi dapat dipakai untuk memprediksi kinerja minat nasabah non muslim menjadi nasabah di Bank Muamalat Indonesia atau dapat dikatakan promosi, fasilitas pelayanan dan lokasi secara bersamasama berpengaruh terhadap masyarakat non muslim menjadi nasabah.

\section{Daftar Pustaka}

Atep Adiya Barata. (2003). Dasar-Dasar Pelayanan Prima. Elek Media Komputindo. Jakarta.

BI dan UMBRAW. (2000). Potensi, Preferensi dan Prilaku Masyarakat Terhadap Bank Syariah: Studi pada Wilayah Jawa 
Tengah. Executif Summary. Jakarta.

Bank Indonesia. (1998). UndangUndang Tentang Perbankan No. 10. Sinar Grafika. Jakarta.

Evi Yupitri dan Raina Linda Sari. (2012). Analisis Faktor-Faktor yang Mempengaruhi Non Muslim Menjadi Nasabah Bank Syariah Mandiri di Medan. Jurnal Ekonomi dan Keuangan, Vol. 1 No. 1.

Hermawan Kertajaya dan Muhammad Syakir Sula. (2006). Syariah Marketing. Mijan Pustaka.

Bandung.

Indriyo Gito Sudarmo. (1997).

Manajemen Pemasaran. BPFE

Yogayakarta. Yogyakarta.

Irsyad Lubis. (2010). Bank dan Lembaga Keuangan Lain. USU Press. Medan.

Kasmir. (2004). Pemasaran Bank. PT. Raja Grafindo Persada. Jakarta.

Kasmir. (2014). Dasar - Dasar Perbankan: Edisi Revisi

2014. Rajawali Pers. Jakarta.

Muhammad Darsyah Siungan. (1990). Lokasi Usaha yang Strategis. Rhineka Cipta. Jakarta.

Muhammad Syafi'i Antonio. (2001). Bank Syariah dari Teori ke Praktek. Gema Insani Press. Jakarta.

Sakti Hutabarat. (2009). Faktor-Faktor yang Mempengaruhi Keputusan Masyarakat Menjadi Nasabah Bank Syariah di Pekanbaru. Jurnal Fakultas Pertanian Universitas Riau. Pekanbaru.

Saladin. (2003). Tim Penyusun Kamus Pusat BahasaIndonesia. Pustaka Abadi. Jakarta.

Sugiono. (2005). Metode Peneitian dan Bisnis. Alfabeta. Bandung.

Yayan Fauzi. (2010). Faktor-Faktor yang Mempengaruhi Nasabah Menabung di Perbankan yariah (Kasus Pada Bank BNI Syariah
Kantor Cabang Yogyakarta). Skripsi Fakultas Syariah UIN Sunan Kali Jaga. Yogyakarta. Zubairi Hasan. (2009). Undang-Undang Perbankan Syariah. PT. Raja Grafindo Persada. Jakarta. 